Materiales de Construcción

Vol. 69, Issue 336, October-December 2019, e205

ISSN-L: 0465-2746

https://doi.org/10.3989/mc.2019.03319

\title{
Comparison between wet and dry timber visual strength grading according to the Spanish (UNE 56544) and German (DIN 4074-1) standards
}

\author{
D.F. Llana ${ }^{\mathrm{a}, \mathrm{b}} \bowtie$, F. Arriaga ${ }^{\mathrm{a}, \mathrm{c}}$, M. Esteban ${ }^{\mathrm{a}, \mathrm{c}}$, G. Íñiguez-González ${ }^{\mathrm{a}, \mathrm{c}}$ \\ a.Timber Construction Research Group, Universidad Politécnica de Madrid (Spain) \\ b. Timber Engineering Research Group, National University of Ireland Galway, Alice Perry Engineering Building, Galway (Ireland) \\ c. Department of Forest and Environmental Engineering and Management, MONTES (School of Forest Engineering and \\ Natural Resources), Universidad Politécnica de Madrid (Spain) \\ $\triangle$ danielfllana@gmail.com
}

\author{
Received 11 March 2019 \\ Accepted 11 July 2019 \\ Available on line 25 September 2019
}

\begin{abstract}
Visual strength grading is widely used to estimate mechanical properties of structural timber. National visual grades are allocated to strength classes according to European standard EN1912. The recent discussion about the proper function of visual strength grading standards and the assignment of strength classes shows the need for further research in this field. Spanish-sourced radiata, Scots, Salzmann and maritime pine timber samples were visually graded in wet and dry condition according to the Spanish UNE56544 (2011) and German DIN4074-1 (2012) standards. Rejection was far higher dry due to distortion (warping) parameters. However, this rejection could be significantly mitigated by adopting a higher twist limit ( $2 \mathrm{~mm} / 25 \mathrm{~mm}$ width). UNE 56544 is more suitable for visually grading these species because it was specifically designed for them and a Spanish source. However, both standards underestimated the Scots pine rejection pieces which mechanical properties fulfill the MEG and S10 grades.
\end{abstract}

KEYWORDS: Wood; Detection of cracks; Mechanical properties; Modulus of elasticity; Dry grading.

Citation/Citar como: Llana, D. F.; Arriaga, F.; Esteban, M.; Íñiguez-González, G. (2019) Comparison between wet and dry timber visual strength grading according to the Spanish (UNE 56544) and German (DIN 4074-1) standards. Mater. Construcc. 69 [336], e205 https://doi.org/10.3989/mc.2019.03319

RESUMEN: Comparación de la clasificación visual de la madera en condiciones húmedas y secas de acuerdo con la norma española UNE 56544 y la alemana DIN 4074-1. La clasificación visual es ampliamente utilizada para estimar las propiedades mecánicas de la madera. Las calidades visuales son asignadas a clases resistentes de acuerdo a la norma europea EN1912. La reciente discusión sobre el apropiado funcionamiento de las normas de clasificación visual y de la asignación de clases resistentes hace necesario seguir investigando sobre el tema. Madera de pino radiata, silvestre, laricio y pinaster fue clasificada visualmente en condiciones húmedas y secas de acuerdo a la norma española UNE56544 y la alemana DIN4074-1. Muchas más piezas fueron rechazadas en seco debido a las deformaciones. Sin embargo, este rechazo se ve significativamente reducido adoptando un nuevo límite de alabeo ( $2 \mathrm{~mm} / 25 \mathrm{~mm}$ ). UNE56544 es más adecuada para la clasificación visual de estas especies pues fue diseñada para ellas y procedencia española. Sin embargo, ambas normas infravaloran el lote rechazado de pino silvestre, cuyas propiedades mecánicas cumplen MEG y S10.

PALABRAS CLAVE: Madera; Detección de fendas; Propiedades mecánicas; Módulo de elasticidad; Clasificación en seco.

ORCID ID: D.F. Llana (https://orcid.org/0000-0001-7758-9456); F. Arriaga (https://orcid.org/0000-0001-5535-0786); M. Esteban (https://orcid.org/0000-0003-3364-9044); G. Íñiguez-González (https://orcid.org/0000-0003-2917-842X)

Copyright: (C) 2019 CSIC. This is an open-access article distributed under the terms of the Creative Commons Attribution 4.0 International (CC BY 4.0) License. 


\section{INTRODUCTION}

Much of the structural timber on the European market is visually graded using national standards. To facilitate the international timber trade, European standard EN 1912:2012 (1) relates the visual grades of European national visual grading standards with the strength classes of EN 338:2016 (2). A revision of EN 1912 was proposed in 2017, and in December 2017 national committees voted to confirm the 2012 version rather than the revision. The main concern involved doubts about the implications of revising the standard. This would involve more than including new national grades approved since 2012 by the Task Group 1 (TG1) of the Working Group 2 (WG2) "Solid Timber" of Technical Committee 124 "Timber Structures" of the European Committee for Standardization (CEN/TC124). According to clause 5.2, Note 2 of EN 1912:2012 (1) "The assignments of grades, species and sources to strength classes given in this document should be reassessed when this document is reviewed, or sooner if there is reason to suspect that the mechanical properties and/or density of the timber have changed, or the basis for the existing assessment no longer represents the current situation, e.g. if there has been a change in the source". That means that every grade should be reassessed in the revision. Grades were assessed in the past in two different ways, according to clause 1: "For the grades, species and sources included, there is long experience of use and/or satisfactory test data". What does "long experience of use" mean here? Could long experience of use be reassessed? The TG1 of CEN/TC124/WG2 raises concerns that some of these "long experience of use" grades may be unsafe, and it considers limiting the grades without test data according to EN $384: 2016+\mathrm{A} 1: 2018$ (3) to the C24 strength class. For example, according to long experience of use, Spanish ME-1 visual strength grade Salzmann pine was allocated to the C35 strength class, and it was shown as such in UNE 56544:1999 (4). However, the test data presented according to EN 384 were considered unsatisfactory by the TG1 of CEN/TC124/ WG2, and it was relegated to C30. In December 2018 CEN/TC124/WG2 decided to request for data justification of strength classes assignment in the EN 1912 by long experience of use to national bodies. Furthermore, according to Stapel and vande-Kuilen (5), some allocations of visual grades in EN 1912 are incorrect, and a review is necessary to include new source area and cross-section limits. Stapel and van-de-Kuilen (6) reported that rejected pieces from Norway spruce at thicknesses of $100 \mathrm{~mm}$ or more fulfilled the required values of mechanical properties for S10 grade. Hermoso et al. (7) found same result on radiata pine at thicknesses of $200 \mathrm{~mm}$ using UNE 56544. Moya et al. (8) applied the idea of a cross-section limit in their proposed non-European visual grading standard for a specific $50 \times 150 \mathrm{~mm}^{2}$ cross-section. Vega et al. (9) proposed combining visual and machine grading with the influence of dimensions. Taking this uncertainty about the proper functioning of visual grading standards into account, the authors consider it to be of interest to compare two national European standards, a Spanish one UNE 56544:2011 (4) and a German one DIN 4074-1:2012 (10), grading wet and dry sawn timber, as well as studying their exactitude in discerning by mechanical properties. Although other scientific works partially covered this topic (11-13) this is the first time using large cross-section timber comparing the Spanish standard which included a specific grade (MEG) for large cross-section with German standard that has not different specifications for large cross-section, beyond that $40 \mathrm{~mm}$ minimum width for Kantholz. Furthermore, a comparison of wet and dry grading in the same batch is important because timber is not always dry graded.

The most relevant singularities considered in visual strength grading for structural sawn timber are knots and grain deviation (14). According to vande-Kuilen and Blass (15) the main features of visual grading standards are based on the most common causes of failure; grain deviation in tropical hardwoods and knots in the case of softwoods, because bending strength decreased with increasing knot size (16). According to Ridley-Ellis et al. (17), visual grading does not accurately grade timber directly into strength classes $(\mathrm{C} 14, \mathrm{C} 16, \mathrm{C} 18, \mathrm{C} 20, \ldots)$, because the latter are so close to each other. Visual grading standards usually classify timber into a small number of grades. Thus UNE 56544:2011 (4) defines a single grade (MEG) for large cross-section timber and two grades (ME-1, ME-2) for small cross-sections. DIN 4074-1:2012 (10) defines three grades (S13, S10 and S7) as well as rejection. In practice, three is the maximum number of grades that can be distinguished according to Ravenshorst (18). Furthermore, strength classes are descriptions of populations, and they do not apply to individual pieces. Therefore, some individual pieces in a population assigned to a strength class may not meet the requirements of the same. Table 1 shows the allocation of visual grades to strength classes according to EN 1912:2012 (1) for the four species studied here.

\subsection{Spanish visual grading standards}

The first Spanish visual grading standard, UNE 56525:1972 (19) was published in December 1972 for structural timber. Seven visual grades were defined (Extra/100, I/80, II/70, III/60, IV/50, V/40 and VI) and no restriction of species was applied. Based on British standard CP112 Part 2:1971 (20) Argüelles and Arriaga (21) published a visual grading proposal with four visual grades for sawn timber 
TABLE 1. Allocation of national standard visual grades to strength classes according to European standard EN 1912:2012 (1) and later approvals for the four species studied.

\begin{tabular}{|c|c|c|c|c|c|c|}
\hline \multirow[b]{4}{*}{ Species } & \multicolumn{6}{|c|}{ Visual grade } \\
\hline & \multicolumn{3}{|c|}{ UNE 56544:2011 } & & & \\
\hline & \multicolumn{2}{|c|}{$\mathrm{b} \leq 70 \mathrm{~mm}$} & \multirow{2}{*}{$\frac{\mathrm{b}>70 \mathrm{~mm}}{\mathrm{MEG}}$} & \multicolumn{3}{|c|}{ DIN 4074-1:2012-06 } \\
\hline & ME-1 & ME-2 & & S13 & $\mathrm{S10}$ & S7 \\
\hline Salzmann pine & $\mathrm{C} 30$ & $\mathrm{C} 18$ & $\mathrm{C} 22$ & - & - & - \\
\hline Scots pine & $\mathrm{C} 27$ & $\mathrm{C} 18$ & $\mathrm{C} 22$ & C30 & $\mathrm{C} 24$ & $\mathrm{C} 18$ \\
\hline Radiata pine & $\mathrm{C} 24$ & $\mathrm{C} 18$ & $\mathrm{C} 20^{\mathrm{a}}$ & - & - & - \\
\hline Maritime pine & $\mathrm{C} 24$ & $\mathrm{C} 18$ & - & - & - & - \\
\hline
\end{tabular}

a approved by CEN/TC124/WG2-TG1 in October 2014 and not yet included in EN 1912

b: piece thickness

$(75,65,50$ and 40) and three for glulam lamellas (LA, LB and LC). UNE 56544 was published in 1997, first covering softwood and hardwood species: radiata, Scots and maritime pine, black poplar and southern blue gum (standard names of the species according to EN 13556:2003 (22)) with two visual grades (ME-1, ME-2) using the characterization work performed in the INIA-CIFOR Structural Timber Laboratory (23) Two years later Salzmann pine was also included (24) and afterwards black poplar was excluded. The results from IñiguezGonzález et al. (25) made it possible to introduce the new visual grade MEG for large cross-section timber (thickness $>70 \mathrm{~mm}$ ) in the standard. That same year, a specific standard only for hardwoods was published as UNE 56546 (26), and since 2013 the scope of this standard includes two species southern blue gum (27) and sweet chestnut (2829), so that UNE 56544:2011 (4) was now only for softwoods. Furthermore, UNE 56547:2018 (30) is a visual grading standard for Scots and Salzmann pine overhead poles.

\subsection{German visual grading standards}

In 1912 the "Illustrierte schweizerische Handwerker-Zeitung" [Illustrated Swiss artisan newspaper] (31) published information about the southwest German timber trade, showing prices and products in the market for wood for paper making, oak, beech, fir and round wood from Baden, Jura and southwest Germany. Before 1938 timber quality grading and the market was organized in Germany by "die Tegernseer Gebräuche" [Tegernsee's customs]. This was based on regional commercial practices such as "die Gebräuche südwestdeutschen Holzhandelsverkehr" [southwest German timber trade usages] from 1922. DIN 4074 was first published in 1938, and it established 3 grades for "Kantholz" structural timber (I high strength, II medium strength and III low strength) based on, among others in knottiness parameters. According to Glos and Richter (32) a reviewed version of
DIN 4074 was published in 1958 including specific visual criteria for "Brett, Bohle und Latte" [board, plank and batten] different from the criterion for "Kantholz" [square timber]. In 1958 DIN 4074-2 (33) was also published for softwood round timber. Machine strength grading was included in 1989. In 2003 DIN 4074-5 (34) was published for hardwoods. The last version of DIN 4074-1 (10) for coniferous sawn timber was published in June 2012.

\subsection{Differences between UNE 56544 and DIN 4074-1}

Each European country developed its own visual grading standards, adapted to their specific timber species' particularities. Nowadays national visual grading standards should meet the minimum requirements established by European standard EN 14081:1:2016 (35). Despite this, differences still exist between national standards. The main differences between UNE 56544:2011 (4) and DIN 4074-1:2012 (10) are: (1.) Scope: UNE 56544:2011 (4) is applied to Spanish-sourced radiata, Scots, Salzmann and maritime pine. DIN 4074-1:2012 (10) is applied to European larch, Norway spruce, Scots pine and silver fir from Central, North and Eastern Europe (CNE), and German-sourced Douglas fir. (2.) Visual grades: UNE 56544:2011 (4) established two visual grades (ME-1, ME-2) for small cross-section timber up to $70 \mathrm{~mm}$ thickness (b), and only one visual grade (MEG) for large cross-section timber $(b>70$ $\mathrm{mm}$ ). DIN 4074-1:2012 (10) established 3 visual grades (S13, S10, S7) for square timber (Kantholz) with $b>40 \mathrm{~mm}$ and $b \leq h \leq 3 b$ and separate requirements for boards and battens. (3.) Knot evaluation: According to UNE 56544:2011 (4) knot size is the width of the knot measured at right angles to the longitudinal axis of the piece, and knot clusters are also considered. According to DIN 4074-1:2012 (10) only single knots are considered in Kantholz, and the smallest diameter of the biggest knot is measured. Furthermore, the smallest knot diameter that should be measured is $10 \mathrm{~mm}$ in the UNE standard 
and $5 \mathrm{~mm}$ in the DIN standard. (4.) Admissible fissure maximum depth values are $2 / 5$ (ME-1) and 3/5 (ME-2, MEG) according to the UNE standard, and 2/5 (S13) and 1/2 (S10, S7) of the thickness dimension according to the DIN standard. Furthermore, fissure depth is measured using a $0.2 \mathrm{~mm}$ feeler gauge in the UNE standard and $0.1 \mathrm{~mm}$ feeler gauge in the DIN standard. (5.) The maximum admissible value of bow distortion is less restrictive according to the UNE standard $(10 \mathrm{~mm} / 2 \mathrm{~m})$ than it is according to the DIN standard (8 $\mathrm{mm} / 2 \mathrm{~m})$.

Several research works compare visual grading by the UNE and DIN standards. Díez et al. (11) graded 776 50x150x3000 $\mathrm{mm}^{3}$ Spanish-sourced Salzmann pine specimens using both standards. When the results of two Spanish visual grades (ME-1, ME-2) were compared with those of three DIN grades (S13, S10, S7) the yields were considered similar. Conde (12) graded Spanish-sourced Salzmann pine and found higher yields using the DIN standard. However, more pieces were graded in the highest UNE visual grade (ME-1) than was the case in the highest DIN visual grade (S13). Esteban (36) and Arriaga et al. (37) compared the visual grading of Scots and maritime pine pieces from existing structures according to the UNE and DIN standards, concluding that there are significant differences in output and that a new assignment of mechanical properties is necessary to complement the strength class system. Adell et al. (13) graded 201 specimens of German-sourced Scots pine, finding higher yields when using the DIN standard. The method used to measure knots was the main reason why rejection rates were higher using the UNE standard.

In this study 100 large cross-section specimens from four different Spanish-sourced species were graded with three main objectives: (1.) to compare visual grading in wet and dry conditions for the same batch of timber, (2.) to compare the results using two visual grading standards: the Spanish UNE 56544:2011 (4) standard and the German DIN 4074-1:2012 (10) standard, and (3.) to evaluate the accuracy of both standards in estimating mechanical properties according to allocation in EN 1912:2012 (1).

\section{MATERIALS AND METHODS}

\subsection{Materials}

One hundred planed large cross-section specimens were tested. They are from four species $(25$ each): radiata pine (Pinus radiata D. Don), Scots pine (Pinus sylvestris L.), Salzmann pine (Pinus nigra Arnold ssp. salzmannii (Dunal) Franco) and maritime pine (Pinus pinaster Ait. ssp. mesogeensis Fieschi \& Gaussen). They are Spanish-sourced and have nominal dimensions of $3000 \mathrm{~mm}$ in length with a $100 \times 150 \mathrm{~mm}^{2}$ cross-section. $44 \%$ of radiata pine,
$68 \%$ of Scots pine, $64 \%$ of Salzmann pine and $56 \%$ of maritime pine pieces contained pith. Wet specimens' ends were sealed in the sawmill to promote uniform drying.

\subsection{Visual grading and mechanical test methods}

Visual grading according to standards UNE 56544:2011 (4) and DIN 4074-1:2012 (10) was performed in wet condition (around FSP) at reception in the laboratory. The global Modulus of Elasticity in bending (MOEg) was obtained in a four point bending test at the same time (around FSP) according to EN 408:2010+A1:2012 (38). Air-drying took 116-180 days depending on the species until a final MC of around 10\% was obtained. Visual grading according to both standards was performed again in dry condition and a four point bending test was applied until failure (obtaining MOEg and bending strength, MOR). The Modulus of Elasticity parallel to the grain (MOE) was calculated from the MOEg previously adjusted to $12 \%$ reference MC, using the expression [1], according to EN 384:2016+A1:2018 (3).

$$
\mathrm{MOE}=\mathrm{MOE}_{\mathrm{g} 12 \%} * 1.3-2690
$$

Where: MOE, modulus of elasticity parallel to grain $\left(\mathrm{N} \mathrm{mm}^{-2}\right) ; \mathrm{MOE}_{\mathrm{g} 12 \%}$, global modulus of elasticity in bending adjusted to $12 \% \mathrm{MC}\left(\mathrm{N} \mathrm{mm}^{-2}\right)$.

Wet specimens were not tested to failure. Therefore, density was determined from the mass and volume of the test specimen and adjusted to the density of a small free-defect prism, by dividing by 1.05 according to clause 5.3.4 of EN 384:2016+A1:2018 (3). Characteristic values (5\%) were calculated according to ranking method, as study was done with relatively few pieces, some of the values were obtained from only one piece being more informative than accurate.

\subsection{Moisture content determination}

Wet MC was estimated by the electrical resistance method according to EN 13183-2:2002 (39). Mean dry MC was determined by the oven dry method after mechanical testing according to standard EN 13183-1:2002 (40), using specimen slices free of knots and resin pockets according to EN 408:2010+A1:2012 (38).

\section{RESULTS AND DISCUSSION}

\subsection{Comparison between wet and dry grading}

Average wet MCs were $32.2 \%, 27.5 \%, 35.8 \%$ and $34.4 \%$ respectively, for radiata, Scots, Salzmann and maritime pine. Average dry MCs were 9.0\%, 10.6\%, 
$9.7 \%$ and $9.2 \%$, respectively. Figure 1 shows the percentage of pieces in each visual grade and rejected using the Spanish UNE 56544 and German DIN 4074-1 standards.

Figure 1 shows major differences between wet and dry grading. High percentages of rejection in dry condition were found using both standards (from $36 \%$ to $84 \%$, depending on the species). The low percentages of rejection in wet condition lead us to think that the parameters that may give rise to a high rate of rejection when dry will be those which are directly linked to $\mathrm{MC}$, such as fissures and distortion. Table 2 shows specimen grades according to visual parameters in dry condition.

The results shown in Table 2 confirm that the high percentages of rejection are mainly due to distortion (mainly by twist parameter). According to EN 14081-1:2016 (35) "dry-graded structural timber shall have at the time it is graded for fissures and distortion, a mean MC of $20 \%$ or less with no individual measurement exceeding $24 \%$ ". Although the other parameters where measured at higher MC, if fissures and distortion were measured according to the standard it is considered to be dry-graded timber (17). As distortion (mainly twist) has the highest influence on rejection of dry graded timber, results from wet grading (mainly based on knots) are not comparable with the ones expected when timber is dry-graded. However, according to Montón et al. (41) distortion has almost no influence in mechanical properties, but reduces the end-use possibilities because the lack of straightness makes difficult the structural high quality uses. EN 14081-1:2016 (35) also shows that in clause A.2.2 "Even if warp of timber does not directly influence strength, it is strongly recommended that timber for building purposes should be subject to some restrictions in this respect”.

\subsection{Comparison between UNE 56544 and DIN 4074-1}

Table 2 shows the dry graded and rejected specimens by several visual parameters. In case of the knot visual parameter, the UNE 56544:2011 (4) standard led to a higher rejection percentages (from $0 \%$ to $20 \%$ ) than the DIN 4074-1:2012 (10) (from $0 \%$ to $12 \%$ ). Furthermore, rejection according to knot parameter using DIN 4074-1:2012 (10) standard was lower than expected. Stapel and van-deKuilen (6), using the same standard for Norway spruce grading, reported really low rejection percentages by knot evaluation when timber thickness is higher than $50 \mathrm{~mm}$, which was the case in the current study $(100 \mathrm{~mm})$. Regarding fissures and slope of grain, as DIN is more restrictive than UNE in these visual parameters, rejection was higher using DIN than UNE. Concerning distortion visual grading parameters (bow, spring and twist), rejection by bow (from $0 \%$ to $20 \%$ ) and spring (from $0 \%$ to $12 \%$ ) parameters were low and similar in both standards. However, rejection by twist parameter was really high for Scots, Salzmann and maritime pine (from $44 \%$ to $80 \%$ ) and low only for radiata pine (8\%). A broader study of the visual grading and mechanical properties of radiata pine revealed that twist is the key singularity for the visual grading yield, mainly in small cross-sections (7). This is in agreement with current results where twist was the key singularity but large cross-section radiata pine were the less affected specimens.

The current twist limit value is the same in both standards ( $1 \mathrm{~mm} / 25 \mathrm{~mm}$ width) according to the maximum value allowed by the European standards. Nevertheless, European standard EN 14081-1:2016 (35) increased, with respect to the previous version, the maximum permissible twist that can be adopted
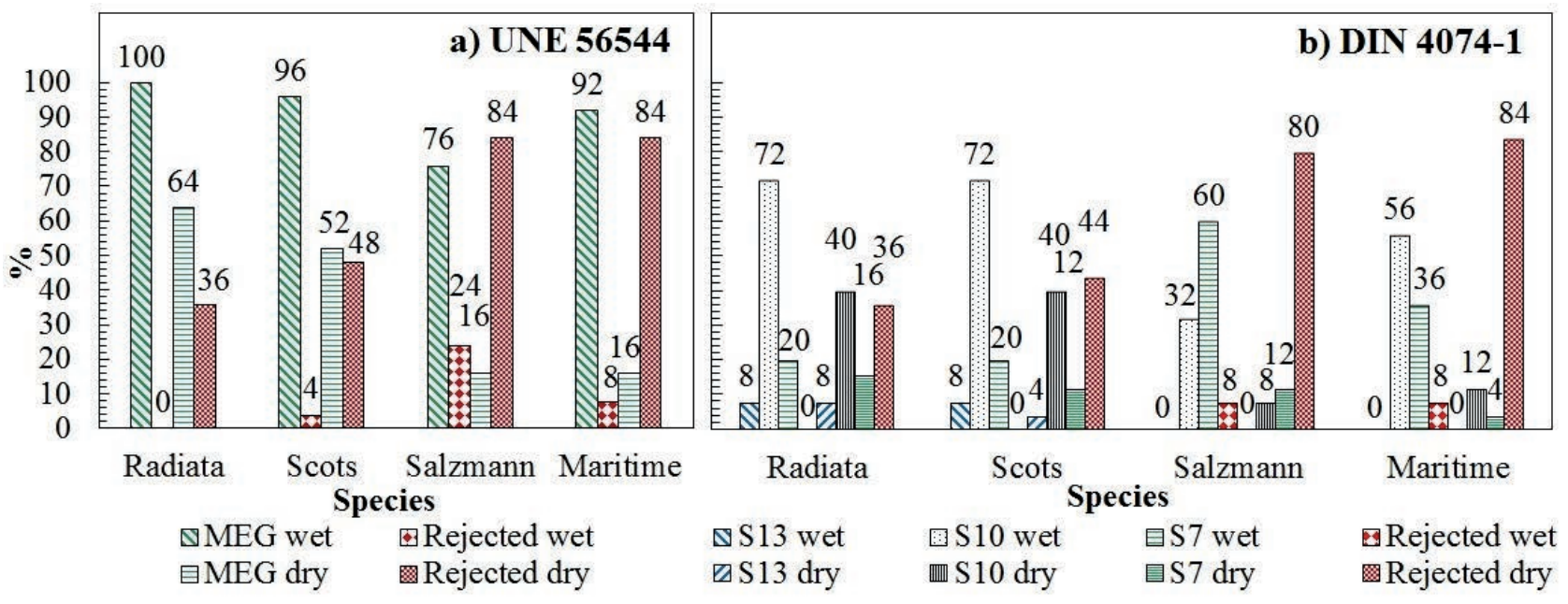

FIGURE 1. Percentages of graded and rejected wet and dry specimens: (a) According to UNE 56544:2011 (4), (b) According to DIN 4074-1:2012 (10). 
TABLE 2. Dry graded and rejected specimens using visual parameters.

\begin{tabular}{|c|c|c|c|c|c|c|c|}
\hline \multirow[b]{2}{*}{$\begin{array}{l}\text { Visual } \\
\text { parameter }\end{array}$} & \multirow[b]{2}{*}{$\begin{array}{l}\text { Species } \\
\text { (pine) }\end{array}$} & \multicolumn{2}{|c|}{ UNE 56544} & \multicolumn{4}{|c|}{ DIN 4074-1 } \\
\hline & & $\begin{array}{c}\text { MEG } \\
(\%)\end{array}$ & $\begin{array}{c}\text { Rejected } \\
(\%)\end{array}$ & $\begin{array}{l}\text { S13 } \\
(\%)\end{array}$ & $\begin{array}{l}\text { S10 } \\
(\%)\end{array}$ & $\begin{array}{l}\mathrm{S} 7 \\
(\%)\end{array}$ & $\begin{array}{c}\text { Rejected } \\
(\%)\end{array}$ \\
\hline \multirow[t]{4}{*}{ Knots } & Radiata & 100 & 0 & 12 & 56 & 32 & 0 \\
\hline & Scots & 96 & 4 & 4 & 64 & 32 & 0 \\
\hline & Salzmann & 80 & 20 & 0 & 28 & 60 & 12 \\
\hline & Maritime & 84 & 16 & 0 & 48 & 48 & 4 \\
\hline \multirow[t]{4}{*}{ Fissures } & Radiata & 100 & 0 & 100 & 0 & 0 & 0 \\
\hline & Scots & 100 & 0 & 92 & 4 & 0 & 4 \\
\hline & Salzmann & 100 & 0 & 96 & 0 & 0 & 4 \\
\hline & Maritime & 100 & 0 & 92 & 8 & 0 & 0 \\
\hline \multirow[t]{4}{*}{ Slope of grain } & Radiata & 100 & 0 & 96 & 4 & 0 & 0 \\
\hline & Scots & 100 & 0 & 100 & 0 & 0 & 0 \\
\hline & Salzmann & 100 & 0 & 96 & 4 & 0 & 0 \\
\hline & Maritime & 96 & 4 & 52 & 40 & 0 & 8 \\
\hline \multirow[t]{4}{*}{ Bow } & Radiata & 80 & 20 & 80 & 0 & 0 & 20 \\
\hline & Scots & 100 & 0 & 100 & 0 & 0 & 0 \\
\hline & Salzmann & 100 & 0 & 96 & 0 & 0 & 4 \\
\hline & Maritime & 84 & 16 & 80 & 0 & 0 & 20 \\
\hline \multirow[t]{4}{*}{ Spring } & Radiata & 88 & 12 & 88 & 0 & 0 & 12 \\
\hline & Scots & 100 & 0 & 100 & 0 & 0 & 0 \\
\hline & Salzmann & 96 & 4 & 96 & 0 & 0 & 4 \\
\hline & Maritime & 92 & 8 & 92 & 0 & 0 & 8 \\
\hline \multirow[t]{4}{*}{ Twist } & Radiata & 92 & 8 & 92 & 0 & 0 & 8 \\
\hline & Scots & 56 & 44 & 56 & 0 & 0 & 44 \\
\hline & Salzmann & 20 & 80 & 20 & 0 & 0 & 80 \\
\hline & Maritime & 24 & 76 & 24 & 0 & 0 & 76 \\
\hline
\end{tabular}


FIGURE 2. Specimens dry graded and rejected percentages using the current twist limit (1 mm) and new possible twist limit (2 mm) in EN14081-1:2016 (35): (a) According to UNE 56544:2011 (4), (b) According to DIN 4074-1:2012 (10).

by national standards from $1 \mathrm{~mm}$ to $2 \mathrm{~mm}$ (/ $25 \mathrm{~mm}$ width) for strength classes above C18. Following the possibility to increase the twist limit value up to $2 \mathrm{~mm}$ in future versions of the UNE 56544 standard,
Figure 2 shows a large decrease in rejection for radiata pine (from $36 \%$ to $12 \%$ ), Scots pine (from $48 \%$ to $16 \%$ ) and Salzmann pine (from $84 \%$ to $60 \%$ ). There was a moderate decrease in case of maritime pine 
(from $84 \%$ to $80 \%$ ) and similar rejection decreases were found when defining a $2 \mathrm{~mm}$ twist limit value in the DIN 4074-1 (Figure 2). According to Montón et al. (41) studying the high influence of distortion in the rejection rate for radiata pine, moderating twist specification from $1 \mathrm{~mm}$ to $2 \mathrm{~mm}$ has no important consequence for mechanical properties.

Therefore, if this new maximum permissible twist limit of $2 \mathrm{~mm}$, according to EN 14081-1:2016 (35), is included in future versions of both studied standards, rejection will be reduced without significant reduction of the mechanical properties. However, twist limit definition is exclusive competence of national standard committees and could follow different criteria than yield or mechanical properties. For example, the twist limit in DIN 4074-1:2012 (10) standard is based on consensus between producers and end-users, taking into account that timber with big distortion cannot be used in highquality structures. In order to avoid timber fulfilling mechanical rejected only by distortion and combine it with industry consensus, $2 \mathrm{~mm}$ twist limit could be adopted only in the lowest grade (S7), using for high-quality structures the higher grades (S13 and S10). Furthermore, any change in national standards should be reported to the TG1 of CEN/ TC124/WG2 including the fulfilling of EN 1912 allocations with the new criteria.

\subsection{Mechanical properties according to visual grade}

As it was explained in Materials and Methods, in the bending test the overall MOEg should be adjusted to $12 \%$ reference MC. According to clause 5.4.2 of EN 384:2016+A1:2018 (3) MC shall be taken to be $18 \%$ when it is higher than $18 \%$, and the value should be adjusted by $1 \%$ for each $1 \%$ of
MC. This means the MOEg obtained in wet condition (around FSP) should be adjusted as if MC were $18 \%$ instead of its actual level. In this work, MOEg values were obtained by testing in wet and dry conditions, so that it is possible to compare actual dry values with those adjusted to $12 \% \mathrm{MC}$ wet values. Table 3 shows these wet MOEg test values together with adjusted MOEg values using different adjustment criteria (from 18\% MC, from 30\% MC, from original wet MC) and dry MOEg adjusted to $12 \% \mathrm{MC}$ and the ratio with respect to dry MOEg expressed in percentage $(100 \%)$.

Table 3 shows that MOEg obtained wet without $\mathrm{MC}$ adjustment were from $74 \%$ to $83 \%$ of MOEg obtained dry and adjusted to $12 \%$. When these wet MOEg were adjusted according to EN 384:2016+A1:2018 (3) MOEg values from 79\% to $88 \%$ of the dry values were found. However, when they were adjusted from $30 \%$ the specimens above this $\mathrm{MC}$ value and the others adjusted from their original MC, values from $88 \%$ to $98 \%$ were found. Finally, adjustment from wet MC reported closer values, which in the case of maritime pine was higher than its dry values being an unsafe adjustment. Adjustment according to the standard looks too conservative, but adjustment from the original $\mathrm{MC}$ is risky. However, adjustment taking $\mathrm{MC}$ as $30 \%$ for MC higher than $30 \%$ is accurate and safe.

Analysis of variance (ANOVA) was applied to visual grade batches according to their mechanical properties adjusted to $12 \%$ according to EN 384:2016+A1:2018 (3). Figure 3 shows UNE 56544 values for Salzmann pine while Figure 4 for DIN 4074-1 shows values for Scots pine, which is the only one of the four species within the German standard but from different source.

TABLE 3. Mean MCs and different MC adjustments of MOEg and percentage from MOEg dry.

\begin{tabular}{|c|c|c|c|c|c|c|c|}
\hline $\begin{array}{l}\text { Species } \\
\text { (wet graded) }\end{array}$ & $\begin{array}{c}\text { Wet MC } \\
\text { mean } \\
(\%)\end{array}$ & $\begin{array}{c}\mathrm{MOE}_{\mathrm{gWET}} \\
\text { mean } \\
\left(\mathrm{N} \mathrm{mm}^{-2}\right)\end{array}$ & $\begin{array}{c}\text { MOE }_{\text {gWET12 } \%} \\
\text { from } 18 \% \\
\text { EN384 } \\
\left(\mathrm{N} \mathrm{mm}^{-2}\right)\end{array}$ & $\begin{array}{c}\text { MOE }_{\text {gWET12\% }} \\
\text { from 30\% } \\
\left(\mathbf{N ~ m m}^{-2}\right)\end{array}$ & $\begin{array}{l}\text { MOE }_{\mathrm{gWET12}} \% \\
\text { from wet MC } \\
\left(\mathrm{N} \mathrm{mm}^{-2}\right)\end{array}$ & $\begin{array}{l}\mathrm{MOE}_{\mathrm{gDRY} 12 \%} \\
\text { from dry MC } \\
\left(\mathrm{N} \mathrm{mm}^{-2}\right)\end{array}$ & $\begin{array}{c}\text { Dry MC } \\
\text { mean } \\
(\%)\end{array}$ \\
\hline $\begin{array}{l}\text { Radiata } \\
\text { (MEG) }\end{array}$ & 32.2 & $\begin{array}{l}8187 \\
81 \%\end{array}$ & $\begin{array}{r}8678 \\
85 \%\end{array}$ & $\begin{array}{l}9563 \\
94 \%\end{array}$ & $\begin{array}{l}9868 \\
97 \%\end{array}$ & $\begin{array}{l}10150 \\
100 \%\end{array}$ & 7.9 \\
\hline $\begin{array}{l}\text { Scots } \\
\text { (MEG) }\end{array}$ & 27.5 & $\begin{array}{l}9142 \\
82 \%\end{array}$ & $\begin{array}{l}9691 \\
87 \%\end{array}$ & $\begin{array}{r}10541 \\
94 \%\end{array}$ & $\begin{array}{r}10563 \\
94 \%\end{array}$ & $\begin{array}{l}11180 \\
100 \%\end{array}$ & 9.5 \\
\hline $\begin{array}{l}\text { Salzmann } \\
\text { (MEG) }\end{array}$ & 35.3 & $\begin{array}{l}7296 \\
74 \%\end{array}$ & $\begin{array}{l}7734 \\
79 \%\end{array}$ & $\begin{array}{l}8608 \\
88 \%\end{array}$ & $\begin{array}{l}8967 \\
91 \%\end{array}$ & $\begin{array}{r}9826 \\
100 \%\end{array}$ & 9.5 \\
\hline $\begin{array}{l}\text { Maritime } \\
\text { (MEG) }\end{array}$ & 34.8 & $\begin{array}{l}6533 \\
83 \%\end{array}$ & $\begin{array}{r}6925 \\
88 \%\end{array}$ & $\begin{array}{l}7705 \\
98 \%\end{array}$ & $\begin{array}{r}8015 \\
\mathbf{1 0 2} \%\end{array}$ & $\begin{array}{r}7859 \\
100 \%\end{array}$ & 10.0 \\
\hline $\begin{array}{l}\text { Scots } \\
\text { (S13) }\end{array}$ & 28.0 & $\begin{array}{c}11408 \\
82 \%\end{array}$ & $\begin{array}{r}12092 \\
87 \%\end{array}$ & $\begin{array}{r}13234 \\
95 \%\end{array}$ & $\begin{array}{r}13234 \\
95 \%\end{array}$ & $\begin{array}{l}13946 \\
100 \%\end{array}$ & 9.7 \\
\hline $\begin{array}{l}\text { Scots } \\
\text { (S10) }\end{array}$ & 27.8 & $\begin{array}{l}9462 \\
83 \%\end{array}$ & $\begin{array}{r}10029 \\
88 \%\end{array}$ & $\begin{array}{r}10929 \\
96 \%\end{array}$ & $\begin{array}{r}10958 \\
96 \%\end{array}$ & $\begin{array}{l}11411 \\
100 \%\end{array}$ & 9.5 \\
\hline $\begin{array}{l}\text { Scots } \\
\text { (S7) }\end{array}$ & 26.4 & $\begin{array}{l}7678 \\
78 \%\end{array}$ & $\begin{array}{l}8138 \\
82 \%\end{array}$ & $\begin{array}{l}8771 \\
89 \%\end{array}$ & $\begin{array}{l}8771 \\
89 \%\end{array}$ & $\begin{array}{c}9903 \\
100 \%\end{array}$ & 9.5 \\
\hline
\end{tabular}

In bold values exceeding $100 \%$ of dry MOE at $12 \%$ 

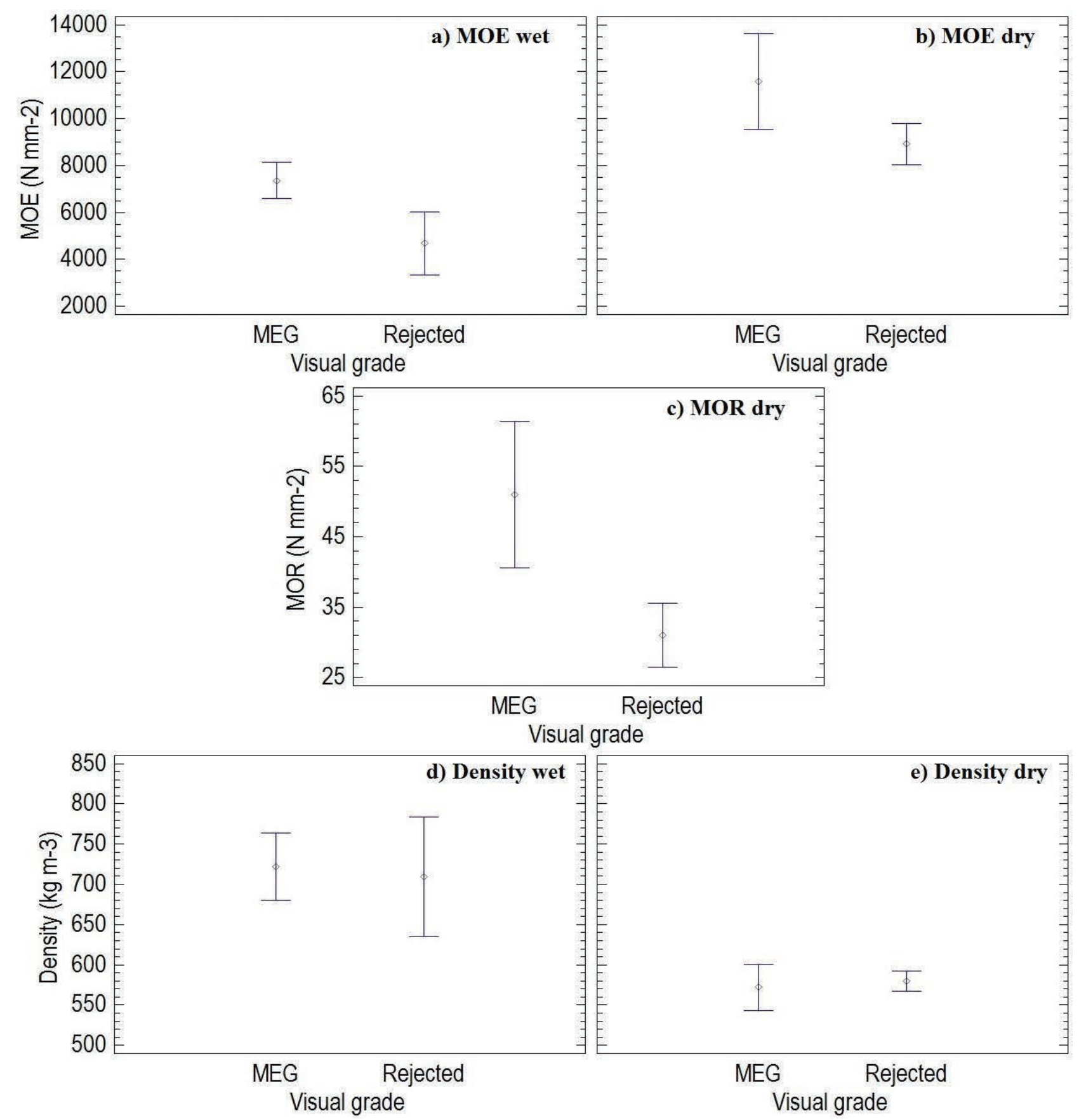

FIgURE 3. Salzmann pine ANOVAs of properties according to visual grade UNE 56544:2011 (4): (a) MOE wet, (b) MOE dry, (c) MOR dry, (d) Density wet, (e) Density dry.

Figure 3 is an example for Salzmann pine. Similar results were found for the other three species studied (radiata, Scots and maritime). Figure 3 shows that although visual grades can discern by MOE wet, MOE values corrected to $12 \% \mathrm{MC}$ according to EN 384:2016+A1:2018 (3) from 18\% to $12 \%$ do not fulfill the required values for the allocated strength class according to EN 1912. For example, the mean MOE corrected to $12 \%$ for MEG wet Salzmann pine is $7364 \mathrm{~N} \mathrm{~mm}^{-2}$, which is less than the $9500 \mathrm{~N} \mathrm{~mm}^{-2}$ (10000x0.95) required for C22. Furthermore, if instead of correcting MOE wet from $18 \%$ to $12 \%$ according to EN 384:2016 (3) it is corrected from the original $\mathrm{MC}$ to $12 \%$ at $1 \%$ change per each $\mathrm{MC} \%$, the corrected MOE will be $8967 \mathrm{~N} \mathrm{~mm}^{-2}$. Visual grades discern MOE and MOR in dry condition. However, it is not possible to discern density values using visual grades. 

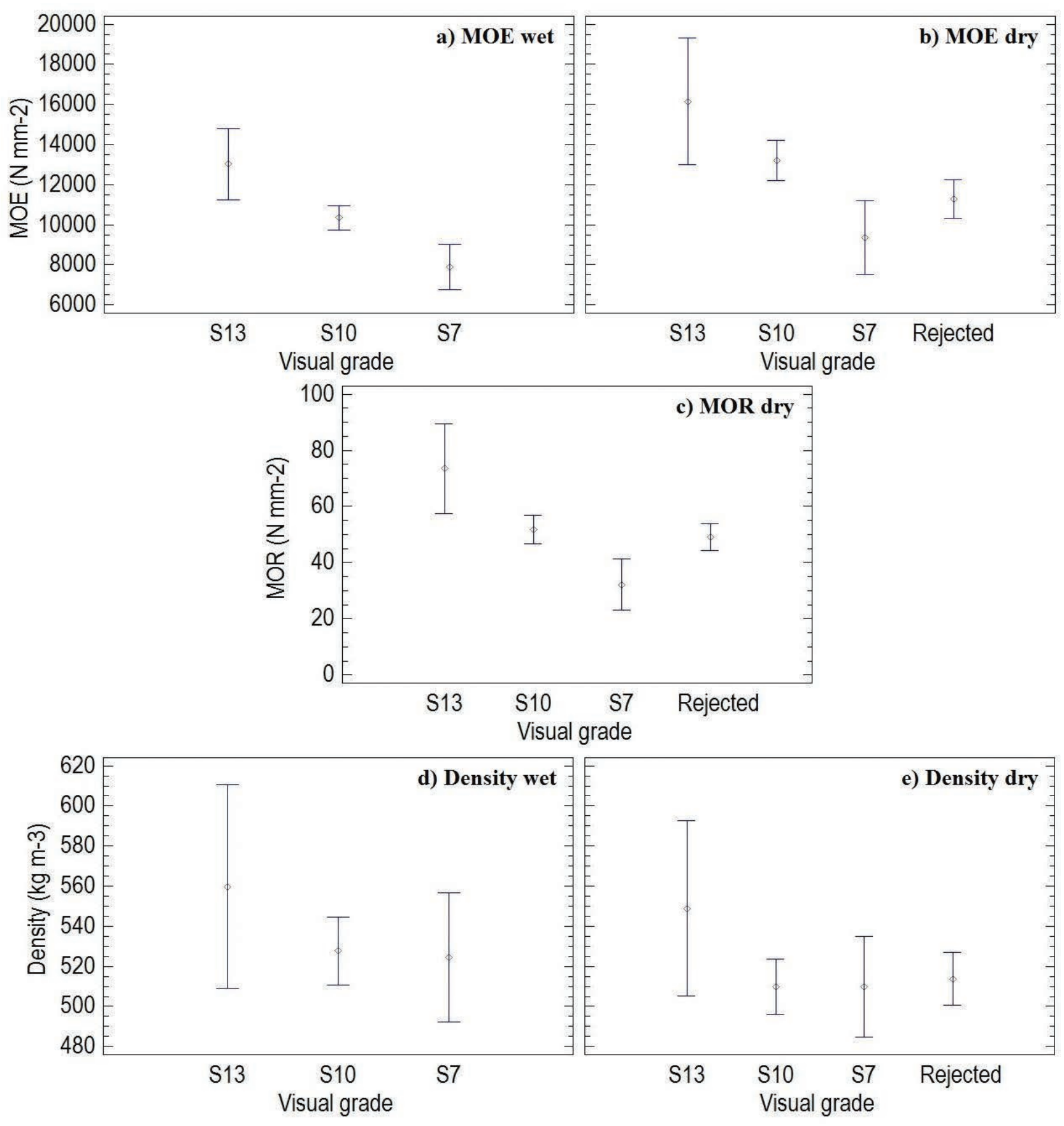

FIgURE 4. Scots pine ANOVAs of properties according to visual grade DIN 4074-1:2012 (10): (a) MOE wet, (b) MOE dry, (c) MOR dry, (d) Density wet, (e) Density dry.

Figure 4 shows that visual grades discern according to MOE values wet at 95\% confidence level. However, the values of MOE corrected to $12 \% \mathrm{MC}$ according to EN 384:2016+A1:2018 (3) (from 18\% to $12 \%$ ) only fulfill the required values in the case of S13 for the allocated strength class according to EN 1912. Mean MOE corrected to $12 \%$ for $\mathrm{S} 13$ wet is $13030 \mathrm{~N} \mathrm{~mm}^{-2}$, which is more than the $11400 \mathrm{~N} \mathrm{~mm}^{-2}$ required for C30. However, S10 $10348 \mathrm{~N} \mathrm{~mm}^{-2}$ is less than the $10450 \mathrm{~N} \mathrm{~mm}^{-2}$ required for $\mathrm{C} 24$, and for $\mathrm{S} 77890 \mathrm{~N} \mathrm{~mm}^{-2}$ is less than $8550 \mathrm{~N} \mathrm{~mm}^{-2}$ for $\mathrm{C} 18$. When dry, the MOE of rejected batch is higher than the S7 batch. The same pattern was found in the case of MOR. In case of density grades, density cannot be distinguished according to visual grade.

Although both standards generally more or less differentiate between the MOE and MOR values of visual grades for graded specimens in wet and dry 
condition, the batch rejected by the DIN standard presented higher values than expected. However, neither of the standards can differentiate between the density of visual grades wet or dry.

Tables 4 and 5 show the values actually obtained and the ones that are required as characteristic values for visual grades according to allocation in the EN 1912:2012 (1) standard, together with the percentages of fulfillment.

Table 4 shows that the batch of radiata pine specimens graded as MEG does not achieve the required C20 MOR value $(19.73<20)$. However, the number of graded specimens (16) is too low for further conclusions to be drawn, and the achieved MOR value (19.73) is very close to the one required (20). Scots and Salzmann pine fulfill the required values of C22. The MEG maritime pine batch could be assigned to $\mathrm{C} 22$ strength class according to the achieved values. Rejected batches from radiata, Salzmann and maritime pine achieved values lower than those required, as was expected. However, the rejected batch of Scots pine (12 specimens) fulfills the required values of strength class $\mathrm{C} 22$. But once again, the number of specimens (12) is too low for further conclusions to be drawn, such as the underestimation reported by Adell et al. (13) for German Scots pine graded using UNE 56544. Furthermore, MEG batch property values are higher than those for the rejected batches. In general UNE 56544:2011 (4) seems to work more or less appropriately in dry conditions for these four Spanish-sourced species, except in the case of Scots pine for which it is underestimated, reducing the yield but in a safe way.

Table 5 shows that the S10 graded batch fulfills the requirements of $\mathrm{C} 30$ and could be graded as S13. Furthermore, the rejected batch meets $\mathrm{C} 24$ strength class values and could be graded at the same level as S10. Rejected specimens fulfilling the C24 (S10) required values was also found by Stapel and vande-Kuilen (6) for Norway spruce at thicknesses of $100 \mathrm{~mm}$ or more, and could be safely assigned to $\mathrm{S} 10$ at thicknesses above $120 \mathrm{~mm}$. In this case DIN

TABLE 4. Characteristic values of four Spanish-sourced pine woods for UNE 56544:2011 (4) dry graded MEG, together with rejected specimens and required strength class values.

\begin{tabular}{|c|c|c|c|c|c|c|c|c|c|}
\hline \multirow{3}{*}{$\begin{array}{l}\text { Species } \\
\text { (EN 1912 } \\
\text { strength } \\
\text { class) }\end{array}$} & \multicolumn{6}{|c|}{ Achieved (EN 408) } & \multirow{2}{*}{\multicolumn{3}{|c|}{$\begin{array}{l}\text { Required } \\
\text { (EN 338) }\end{array}$}} \\
\hline & \multicolumn{3}{|c|}{ MEG } & \multicolumn{3}{|c|}{ Rejected } & & & \\
\hline & $\begin{array}{c}\text { MOE } \\
\text { mean } \\
\left(\mathbf{N ~ m m}^{-2}\right) \\
\end{array}$ & $\begin{array}{c}\text { MOR } \\
5 \% \\
\left(\mathbf{N ~ m m}^{-2}\right) \\
\end{array}$ & $\begin{array}{c}\text { DEN } \\
\mathbf{5 \%} \\
\left(\mathrm{kg} \mathrm{m}^{-3}\right) \\
\end{array}$ & $\begin{array}{c}\text { MOE } \\
\text { mean } \\
\left(\mathbf{N ~ m m}^{-2}\right) \\
\end{array}$ & $\begin{array}{c}\text { MOR } \\
5 \% \\
\left(\mathbf{N ~ m m}^{-2}\right) \\
\end{array}$ & $\begin{array}{c}\text { DEN } \\
5 \% \\
\left(\mathrm{~kg} \mathrm{~m}^{-3}\right) \\
\end{array}$ & $\begin{array}{c}\text { MOE } \\
(\mathbf{x 0 . 9 5 )} \\
\left(\mathbf{N ~ m m}^{-2}\right) \\
\end{array}$ & $\begin{array}{c}\text { MOR } \\
5 \% \\
\left(\mathbf{N ~ m m}^{-2}\right) \\
\end{array}$ & $\begin{array}{c}\text { DEN } \\
5 \% \\
\left(\mathrm{~kg} \mathrm{~m}^{-3}\right) \\
\end{array}$ \\
\hline $\begin{array}{l}\text { Radiata } \\
\text { (C20) }\end{array}$ & $\begin{array}{l}11691 \\
130 \%\end{array}$ & $\begin{array}{l}19.73 \\
\mathbf{9 9} \%\end{array}$ & $\begin{array}{c}432 \\
131 \%\end{array}$ & $\begin{array}{l}8395 \\
93 \%\end{array}$ & $\begin{array}{l}17.99 \\
90 \%\end{array}$ & $\begin{array}{c}426 \\
129 \%\end{array}$ & $\begin{array}{l}9500 \\
(9025)\end{array}$ & 20 & 330 \\
\hline $\begin{array}{l}\text { Scots } \\
(\mathrm{C} 22)\end{array}$ & $\begin{array}{l}12987 \\
137 \%\end{array}$ & $\begin{array}{l}33.26 \\
151 \%\end{array}$ & $\begin{array}{c}484 \\
142 \%\end{array}$ & $\begin{array}{l}10964 \\
\mathbf{1 1 5 \%}\end{array}$ & $\begin{array}{l}23.54 \\
107 \%\end{array}$ & $\begin{array}{c}471 \\
\mathbf{1 3 8} \%\end{array}$ & $\begin{array}{l}10000 \\
(9500)\end{array}$ & 22 & 340 \\
\hline $\begin{array}{l}\text { Salzmann } \\
\text { (C22) }\end{array}$ & $\begin{array}{l}11567 \\
122 \%\end{array}$ & $\begin{array}{l}29.52 \\
134 \%\end{array}$ & $\begin{array}{c}541 \\
159 \%\end{array}$ & $\begin{array}{l}8916 \\
94 \%\end{array}$ & $\begin{array}{c}12.11 \\
55 \%\end{array}$ & $\begin{array}{c}532 \\
156 \%\end{array}$ & $\begin{array}{l}10000 \\
(9500)\end{array}$ & 22 & 340 \\
\hline $\begin{array}{l}\text { Maritime } \\
\text { (None) }\end{array}$ & $\begin{array}{c}9764 \\
103 \% \mathrm{C} 22\end{array}$ & $\begin{array}{c}43.17 \\
196 \% \mathrm{C} 22\end{array}$ & $\begin{array}{c}536 \\
158 \% \mathrm{C} 22\end{array}$ & $\begin{array}{c}6967 \\
73 \% \text { C22 }\end{array}$ & $\begin{array}{c}13.30 \\
60 \% \mathrm{C} 22\end{array}$ & $\begin{array}{c}511 \\
150 \% \mathrm{C} 22\end{array}$ & - & - & - \\
\hline
\end{tabular}

In bold percentages below required or above expected

TABLE 5. Characteristic values of Spanish-sourced Scots pine for DIN 4074-1:2012 (10) dry graded classes S13, S10 and S7, together with rejected specimens and strength class required values.

\begin{tabular}{|c|c|c|c|c|c|c|}
\hline \multirow[b]{2}{*}{$\begin{array}{l}\text { Visual grade } \\
\text { (EN } 1912 \\
\text { strength class) }\end{array}$} & \multicolumn{3}{|c|}{ Achieved (EN 408) } & \multicolumn{3}{|c|}{$\begin{array}{l}\text { Required } \\
\text { (EN 338) }\end{array}$} \\
\hline & $\begin{array}{c}\text { MOE } \\
\text { mean } \\
\left(\mathrm{N} \mathrm{mm}^{-2}\right)\end{array}$ & $\begin{array}{c}\text { MOR } \\
5 \% \\
\left(\mathbf{N ~ m m}^{-2}\right)\end{array}$ & $\begin{array}{c}\text { DEN } \\
5 \% \\
\left(\mathrm{~kg} \mathrm{~m}^{-3}\right)\end{array}$ & $\begin{array}{c}\operatorname{MOE}(\mathbf{x} 0.95) \\
\left(\mathrm{N} \mathrm{mm}^{-2}\right)\end{array}$ & $\begin{array}{c}\text { MOR } \\
5 \% \\
\left(\mathrm{~N} \mathrm{~mm}^{-2}\right)\end{array}$ & $\begin{array}{c}\text { DEN } \\
5 \% \\
\left(\mathrm{~kg} \mathrm{~m}^{-3}\right)\end{array}$ \\
\hline $\begin{array}{l}\text { S13 } \\
\text { (C30) }\end{array}$ & $\begin{array}{l}16155 \\
142 \%\end{array}$ & $\begin{array}{l}73.47 \\
245 \%\end{array}$ & $\begin{array}{c}549 \\
144 \%\end{array}$ & $\begin{array}{c}12000 \\
(11400)\end{array}$ & 30 & 380 \\
\hline $\begin{array}{l}\text { S10 } \\
\text { (C24) }\end{array}$ & $\begin{array}{l}13192 \\
126 \%\end{array}$ & $\begin{array}{l}35.51 \\
148 \%\end{array}$ & $\begin{array}{c}484 \\
138 \%\end{array}$ & $\begin{array}{c}11000 \\
(10450)\end{array}$ & 24 & 350 \\
\hline $\begin{array}{l}\text { S7 } \\
\text { (C18) }\end{array}$ & $\begin{array}{l}9362 \\
109 \%\end{array}$ & $\begin{array}{l}23.54 \\
131 \%\end{array}$ & $\begin{array}{c}498 \\
156 \%\end{array}$ & $\begin{array}{c}9000 \\
(8550)\end{array}$ & 18 & 320 \\
\hline $\begin{array}{l}\text { Rejected } \\
\text { (None) }\end{array}$ & $\begin{array}{c}11295 \\
\mathbf{1 0 8} \% \text { C24 }\end{array}$ & $\begin{array}{c}32.50 \\
135 \% \text { C24 }\end{array}$ & $\begin{array}{c}471 \\
135 \% \text { C24 }\end{array}$ & - & - & - \\
\hline
\end{tabular}

In bold percentages higher than expected fulfilling S10 visual grade 
4074-1:2012 (10) does not work properly for grading Spanish Scots pine being more accurate the Spanish standard as was expected. The reason for this could be the high level of variability between sources due to environmental and silvicultural factors, since national standards optimize grading by taking into account growth conditions, typical cross-sections and silviculture factors. DIN 40741:2012 (10) was specifically designed for German Scots pine and not for Spanish wood. In any case, it is safe to grade Scots pine from Spain using DIN 4074-1:2012 (10), although a large amount of timber is underestimated.

\section{CONCLUSIONS}

Although UNE 56544:2011 (4) and DIN 40741:2012 (10) are suitable standards for visual timber grading, they have some particularities. Comparison of wet and dry grading showed that the visual parameters which lead to the highest rejection rates are ones that are influenced by MC (mainly distortion) when using both standards and many pieces graded when wet may be rejected when dry.

Comparing both standards' dry-graded yields, a higher rejection rate was found using UNE 56544:2011 (4) (20\%) than was the case with DIN 4074-1:2012 (10) (12\%) due to the knot parameter. This was because these standards use different way to evaluate this criterion. Exactly the same high rejection percentages $(36 \%$ to $80 \%)$ were found due to the distortion parameter using both standards. It is strongly recommended that both national standard committees discuss the possibility of increasing the twist value limit up to $2 \mathrm{~mm} / 25 \mathrm{~mm}$ width that it is the maximum permissible according to the last version of EN 14081-1:2016 (35), thereby allowing an increase from $4 \%$ to $32 \%$ in grading yields for UNE 56544:2011 (4) and from 4\% to $28 \%$ for DIN 4074-1:2012 (10). Should be also taking into account that standard changes are not only based on scientific criteria, market demands and implantation costs need to be further evaluated.

Regarding mechanical properties, although visual grades differentiate according to the MOE when wet, most of these graded MOE values do not meet the ones required according to EN 1912:2012 (1). The main reason for this is that the MC adjustment method for MOEg according to EN $384: 2016+\mathrm{A} 1: 2018$ (3) in case of MC higher than $18 \%$ is excessively conservative, with values from $79 \%$ to $88 \%$ of the ones obtained dry. A more accurate $\mathrm{MC}$ adjustment from $30 \%$ is proposed, which would have safe results.

As expected, timber graded using UNE 56544:2011 (4) gives more accurate results showing less underestimated timber (but not better yields) when determining MOE and MOR by visual grade (not density) than DIN 4074-1:2012 (10).
This is because the former standard was designed for the peculiarities of these species: radiata, Scots, Salzmann and maritime pine, and Spanish source, and its visual grade of MEG is especially adapted to large cross-section (thickness $>70 \mathrm{~mm}$ ). The mechanical properties (MOE, MOR and density) of Scots pine rejected specimens should be lower that the required mechanical properties for the grades MEG and S7. However, these rejected specimens fulfill the required values to be graded as MEG (C22) and S10 (C24). Same issue was found in the literature when visual strength grading standards are used for large thicknesses. In any case, there are not safety concerns because it is an issue of underestimation.

The results, based on 100 specimens from four pine species, need to be validated with a larger sample, but gave indications regarding the proper functioning of visual grading standards and the implementations in order to improve the standards that could be discuss in the national committees.

\section{ACKNOWLEDGMENTS}

Funding: This work was supported by Ministerio de Economía y Competitividad [Spanish Ministry of Economy and Competitiveness]. Plan Nacional I+D 2013-2016. Proy.: BIA 2014-55089-P and Plan Nacional I+D+i 2008-2011. Proy.: BIA 2010-18858.

The authors would like to thank Mr. Ramón García Lombardero for his helpful technical assistance in the INIA-CIFOR Structural Timber Laboratory, Madrid, Spain.

Declarations of interest: none

\section{REFERENCES}

1. EN 1912:2012. Structural timber. Strength classes. Assignment of visual grades and species. European Committee of Standardization (CEN), Brussels, Belgium. Released 2012-06-06 as UNE-EN 1912:2012.

2. EN 338:2016. Structural timber. Strength classes. European Committee of Standardization (CEN), Brussels, Belgium. Released 2016-11-08 as UNE-EN 338:2016.

3. EN 384:2016+A1:2018. Structural timber. Determination of characteristic values of mechanical properties and density. European Committee of Standardization (CEN), Brussels, Belgium. Released 2019-03-13 as UNE-EN 384:2016+A1:2019.

4. UNE 56544:1999-2011. Clasificación visual de la madera aserrada para uso estructural. Madera de coníferas [Visual grading for structural sawn timber. Coniferous timber]. AEN/CTN 56 Madera y Corcho, Madrid, Spain. Released 2011-11-08.

5. Stapel, P.; van-de-Kuilen, J.W.G. (2014) Efficiency of visual strength grading of timber with respect to origin, species, cross section, and grading rules: a critical evaluation of the common standards. Holzforschung 68(2):203-2016. https:// doi.org/10.1515/hf-2013-0042

6. Stapel, P.; van-de-Kuilen, J.W.G. (2014) Influence of crosssection and knot assessment on the strength of visually graded Norway spruce. Eur. J. Wood Prod. 72:213-227. https://doi.org/10.1007/s00107-013-0771-7 
7. Hermoso, E.; Mateo, R.; Íñiguez-González, G.; Montón, J.; Arriaga, F. (2016) Visual grading and structural properties assessment of large cross-section Pinus radiata D. Don timber. BioResources 11[2]:5312-5321. https://doi.org/ 10.15376/biores.11.2.5312-5321

8. Moya, L.; Domenech, L.; Cardoso, A.; O'Neill, H.; Baño, V. (2017) Proposal of visual strength grading rules for Uruguayan pine timber. Eur. J. Wood Prod. 75:1017-1019. https://doi.org/10.1007/s00107-017-1208-5

9. Vega, A.; Dieste, A.; Guaita, M.; Majada, J.; Baño, V. (2012) Modelling of the mechanical properties of Castanea sativa Mill. structural timber by a combination of nondestructive variables and visual grading parameters. Eur. J. Wood Prod. 70[6]:839-844. https://doi.org/10.1007/ s00107-012-0626-7

10. DIN 4074-1:2012 Sortierung von Holz nach der Tragfähigkeit - Teil 1: Nadelschnittholz [Strength grading of wood - Part 1: Coniferous sawn timber]. Normenausschuss Holzwirtschaft und Möbel (NHM), Berlin, Germany. 2012-06.

11. Díez, M.R.; Conde, M.; Fernández-Gofín, J.I.; Rosskopf, S. (2000) Clasificación visual de madera estructural de pino laricio (Pinus nigra Arn.): Comparación de resultados usando las normas UNE 56544 y DIN 4074 [Visual grading of structural timber of Salzmann pine (Pinus nigra Arn.): Comparison of results using standards UNE 56544 and DIN 4074]. Inv. Agrar-Sist. Rec. F. 9[2]:375-380.

12. Conde, M. (2003) Caracterización de la madera estructural de Pinus nigra Subsp. Salzmannii. [Characterization of structural timber from Pinus nigra Ssp. Salzmannii]. Doctoral thesis. ETS de Ingenieros de Montes Universidad Politécnica de Madrid. 209 p.

13. Adell, FJ ; Hermoso, E. Arriaga, F; Richter, C. (2008) Comparison of the Spanish visual strength grading standard for structural sawn timber (UNE 56544) with the German one (DIN 4074) for Scots pine (Pinus sylvestris L.) from Germany. Holz. Roh. Werkst. 66:253-258. https:// doi.org/10.1007/s00107-008-0241-9

14. Baño, V.; Arriaga, F.; Soilán, A.; Guaita, M. (2011) Prediction of bending load capacity of timber beams using a finite element method simulation of knots and grain deviation. Biosyst. Eng. 109:241-249. https://doi.org/10.1016/j. biosystemseng.2011.05.008

15. van-de-Kuilen, J.W.G.; Blass, H.J. (2005) Mechanical properties of azobé (Lophira alata). Holz. Roh. Werkst. 63:1-10. https://doi.org/10.1007/s00107-004-0533-7

16. Baño, V.; Arriaga, F.; Guaita, M. (2013) Determination of the influence of size and position of knots on load capacity and stress distribution in timber beams of Pinus sylvestris using finite element model. Biosyst. Eng. 114:214-222. https://doi.org/10.1016/j.biosystemseng.2012.12.010

17. Ridley-Ellis, D.; Stapel, P.; Baño, V. (2016) Strength grading of sawn timber in Europe: an explanation for engineers and researchers. Eur. J. Wood Prod. 74[3]:291-306. https:// doi.org/10.1007/s00107-016-1034-1

18. Ravenshorst, G.J.P. (2015) Species independent strength grading of structural timber. Doctoral thesis. Technische Universiteit Delft. 277 p. PDF file and https://doi. org/10.4233/uuid:b2243d5d-3275-4d93-9378-b39f97a39f02

19. UNE 56525:1972. Clasificación de la madera aserrada de construcción [Visual grading for construction sawn timber]. IRANOR/CTN 56 Madera y Corcho, Madrid, Spain. 1972-12.

20. CP 112-2:1971. The structural use of timber. Metric units. British Standards Institution. London, UK. ISBN 0580 06911 7. Released 1971-06-15

21. Argüelles, R.; Arriaga, F. (1986) Norma de cálculo de estructuras de madera. [Timber structures design standard]. Ed. AITIM. Madrid, Spain. 80-89.

22. EN 13556:2003. Round and sawn timber - Nomenclature of timbers used in Europe. European Committee of Standardization (CEN), Brussels, Belgium. Released 200401-23 as UNE-EN 13556:2004.

23. Fernández-Golfín, J.I.; Díez, M.R ; Gutiérrez-Oliva, A. (1998) Caracterización mecánica de la madera aserrada de uso estructural, clasificada visualmente de acuerdo con la norma UNE56544 [Mechanical characterization of sawn timber for structural use, graded visually in accordance with Spanish standard UNE56544]. Mater. Construcc. 48[252]:45-59. https://doi.org/10.3989/mc.1998.v48.i252.463

24. Fernández-Golfín, J.I.; Díez, M.R.; Baonza, M.V.; Gutiérrez-Oliva, A; Hermoso, E.; Conde, M. van den Eynde, V. (2001) Caracterización de la calidad y las propiedades de la madera de Pino laricio (Pinus nigra Arn. salzmannii) [Quality and properties characterization of timber from Salzmann pine (Pinus nigra Arn. salzmannii)]. Inv. Agrar-Sist. Rec. F. 10[2]:311-331.

25. Íñiguez-González, G.; Arriaga, F.; Barrett, J.D.; Esteban, M. (2007) Visual grading of large structural coniferous sawn timber according to Spanish standard UNE 56544. Forest Prod. J. 57[10]:45-50.

26. UNE 56546:2013. Clasificación visual de la madera aserrada para uso estructural. Madera de frondosas [Visual grading for structural sawn timber. Hardwood timber]. AEN/CTN 56 Madera y Corcho, Madrid, Spain. Released 2013-11-20.

27. Fernández-Golfín, J.I.; Díez, M.R.; Hermoso, E.; Baso, C.; Casas, J.M.; González, O. (2007) Caracterización de la madera de Eucalyptus globulus para uso estructural [Characteristics of Eucalyptus globulus wood for structural purposes]. CIDEU 4:91-100.

28. Correal, E.; Vilches, M.; Iglesias, C. (2013) Clasificación visual de la madera estructural de Castanea sativa del Sistema Mediterráneo Catalán [Visual grading for structural sawn timber of Castanea sativa from Catalan Mediterranean source]. Proceedings of $6^{\circ}$ Congreso Forestal Español. June 10-14. Vitoria, Spain. 12p.

29. Vega, A.; Arriaga, F.; Guaita, M.; Baño, V. (2013) Proposal for visual grading criteria of structural timber of sweet chestnut from Spain. Eur. J. Wood Prod. 71[4]:529-532. https://doi.org/10.1007/s00107-013-0705-4

30. UNE 56547:2018. Clasificación visual de los postes de madera para líneas aéreas [Visual classification for wood overhead poles]. CTN 56 Madera y Corcho, Madrid, Spain. Released 2018-07-02.

31. Newspaper article (1912) Gebräuche im südwestdeutschen holzhandelsverfehr [Uses in the southwest German timber trade]. Illustrierte schweizerische Handwerker-Zeitung, Zurich, Switzerland. 158-159.

32. Glos, P.; Richter, C. (2002) Sortierhilfen und Erläuterungen zur Anwendung der DIN 4074 in der Praxis [Recomendations and explanations on the application of DIN 4074 in practice]. Report No. 02502. Holzforschung München. Munich, Germany. $8 \mathrm{p}$

33. DIN 4074-2:1958 Bauholz für Holzbauteile; Gütebedingungen für Baurundholz (Nadelholz) [Building Timber for Wood Building Components; Quality Conditions for Building Logs (Softwood)]. Normenausschuss Holzwirtschaft und Möbel (NHM), Berlin, Germany. Released 1958-12.

34. DIN 4074-5:2003 Sortierung von Holz nach der Tragfähigkeit - Teil 5: Laubschnittholz [Strength grading of wood - Part 5: Sawn hard wood]. Normenausschuss Holzwirtschaft und Möbel (NHM), Berlin, Germany. Released 2003-06.

35. EN 14081-1:2016. Timber structures - Strength graded structural timber with rectangular cross section - Part 1: General requirements. European Committee of Standardization (CEN), Brussels, Belgium. Released 201605-18 as UNE-EN 14081-1:2016.

36. Esteban, M. (2003) Determinación de la capacidad resistente de la madera estructural de gran escuadría y su aplicación en estructuras existentes de madera de conífera [Determination of the load carrying capacity of large cross-section structural coniferous timber on existing structures]. Doctoral thesis. ETS de Ingenieros de Montes. UPM. Madrid. 365 p. PDF File: http://oa.upm.es/1404

37. Arriaga, F.; Esteban, M.; Relea, E. (2005) Evaluación de la capacidad portante de piezas de gruesa escuadría de madera de conífera en estructuras existentes [Evaluation of the load carrying capacity of large cross section coniferous timber in standing structures]. Mater. Construcc. 55[280]:43-52. https://doi.org/10.3989/mc.2005.v55.i280.205 
38. EN 408:2010+A1:2012. Timber structures. Structural timber and glued laminated timber. Determination of some physical and mechanical properties. European Committee of Standardization (CEN), Brussels, Belgium. Released 2012-09-26 as UNE-EN 408:2010+A1:2012.

39. EN 13183-2:2002. Moisture content of a piece of sawn timber. Part 2: Estimation by electrical resistance method. European Committee of Standardization (CEN), Brussels, Belgium. Released 2002-07-29 as UNE-EN 13183-2:2002.
40. EN 13183-1:2002. Moisture content of a piece of sawn timber. Part 1: Determination by oven dry method. European Committee of Standardization (CEN), Brussels, Belgium. Released 2002-07-29 as UNE-EN 13183-1:2002.

41. Montón, J.; Arriaga, F.; Iñiguez-González, G.; Segués, E. (2015) Warp requirements and yield efficiency in the visual grading of sawn radiata pine timber. BioResources 10[1]:1115-1126. https://doi.org/10.15376/ biores.10.1.1115-1126 